\title{
Interpretation and Construction in Altering Rules
}

\author{
Gregory Klass \\ Georgetown University Law Center, gmk9@law.georgetown.edu
}

Georgetown Public Law and Legal Theory Research Paper No. 12-153

Georgetown Business, Economics and Regulatory Law Research Paper No. 12-038

This paper can be downloaded free of charge from:

https://scholarship.law.georgetown.edu/facpub/1104

http://ssrn.com/abstract=2164419

This open-access article is brought to you by the Georgetown Law Library. Posted with permission of the author. Follow this and additional works at: https://scholarship.law.georgetown.edu/facpub 


\section{Interpretation and Construction in Altering Rules Gregory Klass* \\ October 19, 2012 - DRAFT}

In Regulating Opt-Out: An Economic Theory of Altering Rules, Ian Ayres presents a Big Idea: to understand contract law, we need to understand not only default rules, but also the rules that say when a default does not apply. ${ }^{1}$ The latter Ayres calls "altering rules." Altering rules are the other side of the default coin. You cannot have a default without also having a rule for when it does not hold. Yet contract theorists have to date paid much more attention to how to set the default. They have not thought systematically about how to design rules for avoiding the default. ${ }^{2}$ Ayres's Big Idea is that we stand in need a theory of these altering rules. The article aims to provide such a theory.

This is an important project, and Regulating Opt-Out brings us at least part of the way toward a general theory of altering rules. Ayres's economic approach, however, creates a blind spot that renders his theory incomplete. Ayres focuses almost entirely on one type of altering rule: rules designed to give the parties control over their legal obligations. In doing so, he all but ignores another, equally important type: rules designed to interpret the nonlegal meaning of the parties' agreement.

What is an altering rule? Ayres writes early on that an altering rule is a rule that provides "the necessary and sufficient conditions for displacing a default legal treatment with some particular other legal treatment." ${ }^{3}$ Though Ayres puts the sentence in italics, this cannot be a complete definition. The default rule in Article 2 of the UCC, for example, is that a nonmerchant seller does not warrant that goods are merchantable, but a merchant seller does. ${ }^{4}$ Although being a merchant is sufficient to displace the nonmerchant default, I do not think that Ayres would want to say it is part of an altering rule. It is an example of what Ayres calls a "tailored default." More like a definition is Ayres's statement that "[a]n altering rule in essence says that if contractors say or do this, they will achieve a particular contractual result." ${ }^{5}$

\footnotetext{
* Professor of Law and Associate Dean of Research and Academic Programs, Georgetown University Law Center.

1121 Yale L.J. 2032 (2012).

${ }^{2}$ But see Gregory Klass, Intent to Contract, 95 Va. L. Rev. 1437, 1461-75 (2009) (discussing the design of defaults and "opt-out rules"); id. at 1475-99 (applying the discussion of defaults and opt-out rules to analyze the conditions of contractual validity for four types of agreements).

${ }^{3}$ Ayres, Altering Rules, supra note 1 at 2036.

${ }^{4}$ UCC $2-314$.

${ }^{5}$ Ayres, Altering Rules, supra note 1 at 2036.
} 
I take this to describe the identifying feature of altering rules. An altering rule looks not at who the parties are, the relationship between them, or the type of agreement they are entering into, but at what the parties do. An altering rule says when parties have acted in a way that displaces the default.

How do Ayres's categories of default and altering rules map onto the familiar distinction between rules of interpretation and rules of construction? In a helpful article on the distinction, Lawrence Solum writes that interpretation is "the process (or activity) that recognizes or discovers the linguistic meaning or semantic content of the legal text," whereas construction is "the process that gives a text legal effect (either by translating the linguistic meaning into legal doctrine or by applying or implementing the text). ${ }^{\prime 6}$ Solum's emphasis on texts reflects his article's focus on constitutional law. In contract law, the interpretive data include more than just texts. Contract interpretation attempts to describe the parties' agreement, if there is one. That requires examining not only written texts, but also oral or other non-written communications, as well as industry practice, prior dealings between the parties and their post-formation behavior. But the difference lies not only in the relevant data. In most cases, contract interpretation seeks to recover not semantic content, a text's linguistic meaning, but communicative content: what in the circumstances the parties objectively intended to say with their words and actions. ${ }^{7}$ And when a contract is wholly implied in fact, interpretation aims not even at that. A contract is implied in fact when the parties have not communicated their agreement in any form. In these cases, interpretation seeks out not communicative content, but the parties' objective understanding of their obligations given their acts and the background norms that apply to their situation. In either case, the ultimate question is not semantic content, but whether the parties entered into an agreement and, if so, its content. Courts express this by saying that the goal of contract interpretation is to discover

\footnotetext{
${ }^{6}$ Lawrence Solum, The Interpretation-Construction Distinction, 27 Const. Comm. 101, 101 (2010). See also Arthur Linton Corbin, 3 Corbin on Contracts: A Comprehensive Treatise on the Rules of Contract Law § 534 at 7 (1951) ("By 'interpretation of language' we determine what ideas that language induces in other persons. By 'construction of the contract,' as the term will be used here, we determine its legal operation-its effect upon the action of courts and administrative officials.").

${ }^{7}$ See Paul Grice, Meaning, 66 Phil. Rev. 377 (1957), reprinted in Paul Grice, Studies in the Way of Words 213 (1989); P.F. Strawson, Intention and Convention in Speech Acts, 73 Phil. Rev. 439 (1964).
} 
the parties' intent. ${ }^{8}$ Contract construction is then the process of determining the legal effect of the agreement that the parties intended.

Contract scholars often speak of default rules as rules of interpretation. We use terms like "default interpretations" or "interpretive defaults." This is because we often do not attend to the interpretationconstruction distinction-which is fine, as long as everyone is clear that "interpretation" is being used to include construction. ${ }^{9}$ If we attend to the difference, it is clear that contract default are rules of construction. ${ }^{10} \mathrm{~A}$ default rule determines the legal effect of an act or omission. One reason we associate contract defaults with rules of interpretation is that defaults are often designed to get at what the parties probably intended, or would have intended had they thought about the question. Majoritarian defaults reflect lawmakers best guess at what most parties want out of their contracts. Efficient defaults attempt to anticipate the terms sophisticated self-interested parties should want. But these rules do not require any act of interpretation in the narrower sense. Predicting parties' likely preferences or intentions is not the same as interpreting the parties' intentions in a given case. ${ }^{11}$

Moreover, as Ayres has been arguing since 1989, not all default rules are or should be majoritarian ones. ${ }^{12}$ Penalty defaults are designed not to get at the terms most parties want, but to give one or both parties a new reason to take some action-namely, to opt out of the default. They are designed

${ }^{8}$ Depending on the case, this might mean the parties' objective intent or their subjective intent. See Lawrence Solan, Contract as Agreement, 83 Notre Dame L. Rev. 353 (2007).

${ }^{9}$ When Ayres' uses the word "interpretation," he means only construction. Thus Ayres suggests thinking "of interpretation as a function, $f()$, that relates actions of contractual parties, $a$, and the surrounding circumstances or contexts, $c$, to particular legal effects, e: $e=f(a, c) . "$ Ayres, Altering Rules, supra note 1 at 2046. See also, Klass, Intent to Contract, supra note 2 (using "interpretation" to refer to construction).

${ }^{10}$ Corbin recognized something like this point in the first edition of his treatise: "When a court is filling gaps in the terms of an agreement, with respect to matters that the parties did not have in contemplation and as to which they had no intention to be expressed, the judicial process . . . . may be called 'construction'; it should not be called 'interpretation.'" Corbin, supra note $6, \S 534$ at 9 .

${ }^{11}$ For a variation on this point, see Seana Valentine Shiffrin, Must I Mean What You Think I Should Have Said?, 98 Va. L. Rev. 159, 163 (2012); Gregory Klass, To Perform or Pay Damages, 98 Va. L. Rev. 143, 145-47 (2012).

${ }^{12}$ Ian Ayres \& Robert Gertner, Filling Gaps in Incomplete Contracts: An Economic Theory of Default Rules, 99 Yale L.J. 87 (1989). 
precisely not to reflect the parties' preferences, and not to map onto their likely intentions.

Altering rules are also rules of construction. They determine the legal effect of what the parties say or do. Ayres focuses on one type of altering rule: rules that are designed to help parties get the legal outcomes they want, though as Ayres points out, such rules also might attempt to slow parties with extra transaction costs. For reasons explained below, and for lack of a more elegant term, I will call these "juristic" altering rules. There is however, a second type of altering rule: rules that turn on the nonlegal meaning of the parties' words and actions. These rules are not designed to enable parties to get the legal outcomes they want, but to make legal outcomes depend on facts about the world that might have nothing to do with the parties' legal intent. I will call these "hermeneutic" altering rules, another term ugly enough to be safe from kidnappers. Because hermeneutic altering rules are less familiar to readers of Regulating Opt-Out, I begin with them.

Negotiations, offers, acceptances, agreements, releases, repudiations and the like are things that happen in the world, whether the law pays attention to them or not. Hermeneutic altering rules are rules of construction start from the best interpretation of the nonlegal meaning of such acts. Was, for example, the defendant's statement an offer to enter into a contract, or was it better understood as a joke? What does "all loss, damage, expense and liability resulting from injury to property" mean to sophisticated parties when it appears in an indemnification clause? Did the plaintiff's actions express an clear intent to breach? The rule then specifies the legal effect of one or another meaning. If the statement was an offer, it gave the plaintiff the power of acceptance. If the indemnification clause referred to party losses, the defendant must pay for damage to the plaintiff's property. If the plaintiff's actions expressed an intent not to perform, she repudiated the contract and was the first to breach. Section 202 of the Second Restatement is a nice example of a general hermeneutic altering rule: "Words and other conduct are interpreted in light of all the circumstances and if the principal purpose of the parties is ascertainable it is given great weight." ${ }^{13}$ When determining the parties' legal obligations, an adjudicator should give "great weight" to the reasonable, all-thingsconsidered meaning of the parties' agreement.

If we take hermeneutic altering rules as our model, it is natural to assume that interpretation comes first, construction second. As Corbin put the point, "[t]he interpretation of communications is necessary as a preliminary to the determination of their legal operation or total lack of

\footnotetext{
${ }^{13}$ Restatement (Second) of Contracts § 202(1).
} 
legal operation." ${ }^{14}$ A court first must decide what a text means before it can decide the legal consequences of that meaning.

Although this ordering is correct from the perspective of courts, it does not describe how other legal actors think about interpretation and construction. Because Ayres is an economist, he is mostly interested in the incentives that rules of construction create. Specifically, he is interested in the incentives they create for legally sophisticated parties entering into a contract. To these legal actors, rules of construction look more like instructions, telling them how to get the legal obligations they want and avoid those they would rather not have. From the perspective of sophisticated parties, rules of construction often come first. These parties use those rules to guide their actions. More to the point, the meaning of sophisticated parties' actions can be understood only by reference to the rules the determine those actions legal effects (though those legal effects might not exhaust that meaning). ${ }^{15}$ Here the rules of construction come first.

Juristic altering rules are designed on the assumption that parties will treat the rule as instructions for how to get the legal outcome they prefer. These rules typically require parties to perform what Germans call a "Rechtsgeschäft," which can be translated as a "juristic act."

The juristic act . . . is a declaration of private will

[Privatwillenserklärung] directed at the realization of a legal effect, an effect that follows on the authority of the legal system because it is willed. The essence of the juristic act is found in the fact that a will directed at the realization of the legal effect is confirmed, and that the legal system issues a judgment, in recognition of that will, that gives legal effect to the desired legal arrangement. ${ }^{16}$

In contract law, the most obvious juristic acts are what Ayres calls "passwords", by which he means legal formalities. ${ }^{17}$ A legal formality is a

${ }^{14}$ Corbin, supra note $6, \S 534$ at 9 .

${ }^{15}$ This way in which interpretation presupposes an understanding of the rules of construction differs form Corbin's suggestion that judicial "interpretation will vary with the construction that must follow." Corbin, supra note $6, \S 534$ at 10 . Corbin is talking here about rules of construction, such as contra proferentem, that direct courts how to choose between different available interpretations.

${ }^{16} 1$ Motive zu dem Entwurfe Eines Bürgerlichengesetzbuches für das Deutsche Reich, 126 (Berlin \& Leipzig, J. Guttentag 1888) (Ger.) (author's translation).

${ }^{17}$ Ayres, Altering Rules, supra note 1 at 2080-83. These are what P.F. Strawson called "conventional" speech acts. Strawson, supra note 7 at 457; 
speech act whose meaning lies first and usually foremost in its legal effect. By requiring an act that has no other meaning or effect-such as writing the words "locus sigilli" or "L.S." on a document-lawmakers can be sure that parties are acting with the desired legal purpose. Alternatively, as Ayres points out, judicial interpretation can turn ordinary boilerplate into something like a formality. A court's interpretation of a string of words can give it a legal meaning very different from its everyday semantic and presumptively communicative content. When used by sophisticated parties, the meaning of those words can be understood only by reference to the rule of construction that determines their legal effect. ${ }^{18}$ But not all juristic altering rules require that the parties perform a formal legal act. Williston's Model Written Obligations Act, for example, provides that a signed promise "shall not be invalid or unenforceable for lack of consideration, if the writing also contains an additional express statement, in any form of

see also Kent Bach \& Robert M. Harnish, Linguistic Communication and Speech Acts 120-34 (1979).

${ }^{18}$ Ayres, Altering Rules, supra note 1 at 2082. James Oldham provides a wonderful example. For centuries, the standardized language in a Lloyd's marine insurance policy described the covered risks as follows:

Touching the Adventures and Perils which we the Assurers are contented to bear and do take upon us in this Voyage, they are, of the Seas, Men-of-War, Fire, Enemies, Pirates, Rovers, Thieves, Jettisons, Letters of Mart and Counter- mart, Surprisals, Takings at Sea, Arrests, Restraints and Detainments of all Kings, Princes, and People, of what Nation, Condition or Quality soever, Barratry of the Master and Mariners, and of all other Perils, Losses and Misfortunes that have or shall come to the Hurt, Detriment, or Damage of the said Goods and Merchandises and Ship, \&c., or any Part thereof.

In his 1914 treatise, Sir Douglas Owen observed, "If such a contract were to be drawn up for the first time to-day, it would be put down as the work of a lunatic endowed with a private sense of humour."

It is an ancient and incoherent document, occasionally the subject of judicial remarks in the highest degree uncomplimentary. But nobody minds this or dreams of altering the ancient form, nor, one may imagine, is it ever likely to be altered. Insurance experts know-or very often know-exactly what it means, and with generations of legal interpretations hanging almost to every word, and almost certainly to every sentence, in it, it would be highly dangerous to tamper with it.

Sir Douglas Owen, Ocean Trade and Shipping 158, 155 (1914). See also James C. Oldham, Insurance Litigation Involving the Zong and other British Slave Ships, 1780-1807, 28 J. Legal Hist. 299 (2007). 
language, that the signer intends to be legally bound." ${ }^{19}$ The proposed rule requires only an express statement of an intent to depart from the noenforcement default. It does not specify in what words that intent must be expressed. Nonformal juristic altering rules, like hermeneutic rules, require interpretation. If a court were ever asked to apply the Model Written Obligations Act, it would have to first ask whether the writing contained an express statement of an intent to be legally bound. But the question is a very narrow one: Does the writing express the requisite legal intent, not what is its overall meaning.

Before turning to the implications for Ayres's project, two more general observations about the difference between hermeneutic and juristic altering rules. First, each type is loosely associated with a distinct function of contract law. ${ }^{20}$ Juristic altering rules, which look for an expression of the parties' legal intent, give parties greater control over their legal obligations to one another, expanding party autonomy. Juristic rules make it easier for parties to use contract law to engage in form of private legislation. They serve the purpose of conferring on private persons a limited lawmaking power. Hermeneutic altering rules, on the contrary, are often designed to get at the nonlegal meaning of the parties' communications and other acts, meanings that cannot be defined in advance. Such rules give the parties somewhat less control over the legal consequences of what they do, for they do not provide the safe harbors of legal formalities. Hermeneutic rules are more suited to taking account of the parties' nonlegal duties, such as the moral obligation to perform. Or to make the same point from the other direction, if we want contract law to take account of parties' actual moral obligations, adjudicators must sometimes be called on to interpret the nonlegal meaning of what they say and do. Hermeneutic rules further the purpose of using contract law to impose duties on parties, not because they want those duties but for other reasons.

That said, the connection between almost any legal rule and its function is a loose one. I have been speaking as if an altering rule is either hermeneutic or juristic. The second point is that many rules of contract law are a mix of the two. A simple example is a written gratuitous promise under seal in a jurisdiction that still recognizes that formality. Enforcement here turns on the formal act of affixing a seal. The rule is juristic. But the legal content of the obligation depends on what the document says. That requires interpretation, and so the rule is hermeneutic. I argue below that the rule in Jacob \& Youngs $v$. Kent is a more subtle sort of mixed rule. For

${ }^{19}$ Model Written Obligations Act $\S 1$, in Handbook of the National Conference of Commissioners on Uniform State Laws and Proceedings of the Thirty-Fifth Annual Meeting 584 (1925).

${ }^{20}$ See Gregory Klass, Three Pictures of Contract: Duty, Power and Compound Rule, 83 N.Y.U. L. Rev. 1726 (2008). 
the moment, I simply want to emphasize that a single altering rule might include both hermeneutic and juristic elements. By the same token, it would be a mistake to assume that hermeneutic altering rules are always associated with contract law's duty-imposing function, or that juristic altering rules are associated with its power-conferring aspect.

So what does all this tell us about Ayres's analysis? Ayres is much more interested in juristic altering rules than he is in hermeneutic ones. This explains the repeated mining of Microsoft UX guidelines for design tips. Ayres cares about rules that, like software menus or dialog boxes, operate as instructions to parties, rules that tell them how to get the terms they want. The focus on juristic altering rules also explains Ayres's attempts to distinguish the rules he cares about from "the larger law of interpretation," which I read to mean altering rules more generally. ${ }^{21}$ The rules he will discuss, Ayres writes, provide "a small set of sought-after alternatives to the default" and are "more often concerned with the necessary and sufficient elements for displacement." ${ }^{22}$ Both hermeneutic and juristic altering rules specify the legal effect e of an act a. Broadly speaking, therefore, both describe necessary, sufficient, or necessary and sufficient conditions for legal change. But a hermeneutic rule typically says that the scope of $e$ reflects the meaning of a. That meaning, in turn, is not given by a legal rule, but depends on an open-ended interpretive inquiry. ${ }^{23}$ As Corbin puts the

${ }^{21}$ Ayres, Altering Rules, supra note 1 at 2045-46. As I observed above, Ayres uses "interpretation" to mean what I am calling "construction." See supra note 9.

22 Ayres, Altering Rules, supra note 1 at 2047. I do not think that Ayres should commit himself to another claim in the same paragraphs: that altering rules often apply where "the default potentially being displaced is not blank," that is, where there is not already a contractual duty. It is true that, in contemporary contract law, telling whether the parties have moved from a no-duty state to a duty state typically requires an all-thingsconsidered interpretive inquiry. But that is only because the contemporary conditions of contractual validity are hermeneutic rules. They require actual agreement, objective or subjective, as distinguished from the performance of this or that juristic act. Other legal systems at other times have employed juristic conditions of contractual validity, such as the Roman stipulatio or the common law seal. Such rules provide precise instructions how to move from a no-duty to a duty state. And if we broaden our definition of "contract law" a bit to include things like corporate law, which governs the agreement-based obligations among owners and managers, we find many juristic altering rules for moving from no-duty to duty states.

${ }^{23}$ For a brief description of those rules, see Gregory Klass, Meaning, Purpose and Cause in the Law of Deception, 100 Geo. L.J. 449, 457-60 (2012) 
latter point, "[t]here is no single rule of interpretation of language, and there are no rules of interpretation taken all together, that will infallibly lead to the one correct understanding and meaning." ${ }^{24}$ Interpretive rules cannot, therefore, be reduced to a simple list of necessary and sufficient conditions, and interpretation can produce an unlimited number of meanings. And because they incorporate interpretation, hermeneutic altering rules neither specify menus of legal outcomes nor identify necessary or even sufficient simple acts that will produce them. Juristic rules, on the contrary, typically identify the legal effect $e$ in advance, and then require a formal act a or some other expression of an intent to achieve that effect. Juristic rules are therefore more likely to provide a menu of legal effects and to describe a set of necessary and/or sufficient acts to achieve them. In short, the features that Ayres identifies as characteristic of the altering rules he cares about are characteristic of juristic altering rules.

Ayres's nearly exclusive interest in juristic altering rules is fine as far as it goes. One of the most important contributions of the economic analysis of contract law has been to give us a better understanding of how legal rules can influence party decisionmaking. Economic analysis of private law has largely focused on how backward-looking decisions about litigants' rights and obligations affect the forward-looking incentives of future parties. That feedback effect appears throughout the law. Deterrence presupposes it. But its operation in the law of contract is a bit more complex than elsewhere. Contract law not only gives parties a new reason to perform their agreements, but also gives them the ability to undertake new legal obligations to one another. Unlike other areas of the law, the rules of contract law feedback to influence not only the decision whether or not to commit a legal wrong, but also the decision whether and how to incur the legal duty. The rules influence parties not only at the time of performance, but also at the time of formation. Ayres's focus on juristic altering rules, like his earlier discussions of penalty defaults, helps us to think systematically about those important effects. ${ }^{25}$

${ }^{24}$ Corbin, supra note $6, \S 535$ at 13 .

${ }^{25}$ One of the crucial, and often overlooked claims, of the theory of efficient breach is that remedial rules affect not only the performance-breach decision, but also the parties' decision at the time of performance. The idea can be found as early as 1972, in John H. Barton's The Economic Basis of Damages for Breach of Contract, which emphasizes the remedy's impact on quantity term. 1 J. Legal Stud. 277 (1972). More recently, Richard Craswell has emphasized its effect on price. Richard Craswell, Promises and Prices, 45 Suffolk U. L. Rev. 735 (2012); see also Daniel Markovits and Alan Schwartz, The Myth of Efficient Breach: New Defenses of the Expectation Interest, 97 Va. L. Rev. 1939 (2011). 
That said, I believe that Ayres's near exclusive focus on juristic altering rules distorts his analysis. Ayres's theory fails to recognize why we sometime prefer hermeneutic altering rules. The omission is glaring in Table 3 , which classifies legal rules according to whether they specify, first, a menu of alternatives to the default and, second, a (juristic) altering rule. ${ }^{26}$ Ayres suggests that rules that do not "give guidance about either the nondefault options or the mechanisms for achieving them" are characteristic of "'immature' regimes where the accretion of precedent has not provided judicial disclosure guidance about particular mechanisms that are sufficient to achieve particular alternatives. ${ }^{27}$ But as I argued above, this also describes hermeneutic altering rules. Because interpretation requires an allthings-considered inquiry into the nonlegal meaning of the parties' acts, hermeneutic altering rules cannot be formulated in terms of simple sufficiency conditions. And because hermeneutic rules provide legal effect should reflect that meaning, they do not provide menus of possible legal outcomes. If it is among the functions of a mature contract regime to track or otherwise take account of the parties' moral or other nonlegal obligations, contract law will include rules of this type. Their existence is not a sign of immaturity, but of the various functions that contract law serves.

The category of hermeneutic rules also cast new light on why juristic altering rules so often specify sufficient but not necessary conditions for non-default terms. Ayres identifies three possible goals in the design of altering rules: minimizing transaction costs, reducing error, and impeding departures from the default. Error-reduction and impedance both require necessary altering rules-rules that limit how parties can avoid the default. Error-reduction is achieved by rules that require clear language, enhanced manifestations of assent or procedures that train parties. ${ }^{28}$ Impedance rules establish speed bumps and roadblocks, mechanisms that work only if there are no alternate routes to non-default terms. Ayres suggests that nonnecessary altering rules can work to minimize transaction costs, the third possible design goal. But his argument unconvincing. Ayres writes:

Giving effect to a multiplicity of methods [to avoid the default] reduces the costs of learning the law-especially the necessity to learn the altering rules themselves. A contract law that includes necessary elements for displacement will tend to increase the cost

${ }^{26}$ Ayres, Altering Rules, supra note 1 at 2052.

${ }^{27}$ Id. at 2053.

${ }^{28}$ Id. at 2072-83. 
of becoming (and remaining) informed of the requisite procedures for displacement. ${ }^{29}$

Although a multiplicity of methods might lower the costs to the drafting party, it can significantly increase the costs of understanding the agreement for the nondrafting party. To be certain of the legal significance of the agreement, a nondrafting party must be certain of the legal effects of all of its pieces. The more ways there are of saying the same thing, the more the nondrafting party will need to know if she is to understand what it is she is signing. And Ayres appears to be advocating open lists of displacement procedures, to which new methods of opting-out can be added. Far from reducing the costs of remaining informed, allowing additions to the list increases those costs. This is especially so if the additions are not pure legal formalities-acts that have no nonlegal meaning, or what Ayres calls "passwords" — but emerge from judicial interpretation of party-drafted contract language. When boilerplate comes to have a formal legal meaning, it may not be obvious to the nondrafting party that the words are now magic ones. The nondrafting party might not realize that those words now constitute a juristic act, rather than expressing their original, nonlegal meaning. If we want to minimize transaction costs, sufficient and necessary altering rules are the way to go. At the very least we should expect necessary rules in the form of the Model Written Obligations Act that require "an additional express statement, in any form of language," of the signer's legal intent. ${ }^{30}$

So what explains the fact that many altering rules in our law of contract stipulate sufficient but not necessary ways to contract out of the default? Consider Ayres's own example: Cardozo's opinion in Jacob \& Youngs v. Kent. ${ }^{31}$ Ayres helpfully observes that if Cardozo really wanted a rule that, as Cardozo wrote, would enable parties "by apt and certain words to effectuate a purpose that performance of every term shall be a condition of recovery," Cardozo would have done well to "drop a footnote identifying what language would be sufficient" to achieve that purpose. ${ }^{32}$ That said, it is clear from the opinion that an express intention to condition payment on perfect tender is enough. Although Cardozo might have helped future parties by providing them with a legal formality, the rule he announced is at least as good as that in the Model Written Obligations Act.

${ }^{29}$ Id. at 2055 (footnote omitted). See also id. at 2081-82 (arguing that the best "password altering rules ... are nonexclusive means-and are merely sufficient safe harbors - for achieving particular contractual concerns").

${ }^{30}$ Supra note 19.

31 Jacob \& Youngs, Inc. v. Kent, 129 N.E. 889 (N.Y. 1921).

32129 NE. at 891; Ayres, Altering Rules, supra note 1 at 2056 (emphasis added). 
What Ayres's juristic theory cannot explain is why an express intent to opt-out of the substantial-performance condition is not necessary to avoid the default. Cardozo's opinion provides the answer. When the parties have not expressed an intention one way or another, "[c]onsiderations partly of justice and partly of presumable intention are to tell us" whether their promises are independent, fully dependent, or dependent only on substantial performance. ${ }^{33}$ To reach that determination, "[w]e must weigh the purpose to be served, the desire to be gratified, the excuse for deviation from the letter, the cruelty of enforced adherence." ${ }^{134}$ The first two parts of Cardozo's famous test-the purpose of the term that has been breached and the desire that is meant to gratify-call for interpretation of the parties' agreement. Only by an open-ended inquiry into the natural and reasonable understanding of the parties' purposes in specifying Reading pipe and the foreseeable harm to the homeowner from breach of that term could the court determine whether the homeowner's duty to pay was conditional on the builder's perfect performance of the term. The rule here is an altering rule. Whether the duties are independent or dependent depends on what the parties said or did in reaching their agreement. But "what the parties said or did" refers not only to their performance vel non of the appropriate juristic act. It refers also to acts with the right nonlegal meanings, to the parties' actual agreement.

Another way of putting the point is that whereas Cardozo's opinion focuses on the hermeneutic at the expense of the juristic, Ayres makes the opposite mistake. Ayres reads Jacob \& Youngs $v$. Kent as establishing only a juristic altering rule, though in fact Cardozo's primary concern is to explain a hermeneutic one. More generally, altering rules often "provide a nonprolix, nonexclusive set of sufficiency rules" not to minimize transaction costs, but because contract law is about more than effecting the parties' legal purposes, limited only by a bit of hard paternalism and the desire to prevent negative externalities. If we want a contract law sensitive to the parties' nonlegal obligations, we also want altering rules that tell courts to look to the nonlegal meaning of what they say and do. To leave room for the operation of such hermeneutic altering rules, juristic rules must provide only non-necessary conditions for legal change.

This last point suggests a related one: Ayres's account of why we sometimes want sticky defaults and impeding altering rules is incomplete. Ayres adopts the economist's view that there are only two possible justifications for restricting freedom to contract: "to protect people inside (paternalism) or outside (externalities) the contract." ${ }^{35}$ Neither captures society's possible interest in enforcing the moral obligation to perform, in

\footnotetext{
33129 N.E. at 890.

34129 N.E. at 891.

${ }^{35}$ Ayres, Altering Rules, supra note 1 at 2084.
} 
doing justice between the parties after breach, or in supporting the moral culture of making and keeping agreements. Those and related dutyimposing functions of contract law recommend rules whose primary purpose is not to assist the parties in achieving the legal change they want. There are two important consequences. First, hermeneutic altering rules often impose transaction costs not to protect parties or third parties, but as a side effect of their attempt to seek out the objectively reasonable, all-thingsconsidered understanding of the parties agreement. Such transaction costs are the acceptable if unintended consequences of rules whose primary function is not to promote party choice. Second, the duty-imposing function of contract law suggests a third reason for sometimes purposively increasing the costs of opting out, for adopting impeding altering rules. As I have written elsewhere:

Stickier defaults, and by implication costlier opt-outs, . . . can mediate between the sometimes conflicting interests the law has in, on the one hand, granting parties the power to control the scope of their legal obligations and, on the other hand, imposing liability on parties because of extralegal wrongs they have committed, harms they have caused, or other considerations. ${ }^{36}$

This mediating function is exemplified in the conditions of contractual validity. "By combining an enforcement default with a relatively costly optout rule, we can permit sophisticated and sufficiently motivated parties to avoid legal obligations they would otherwise owe one another without significantly impairing the duty-imposing functions of contract law. ${ }^{137}$ In Ayres's idiom, impeding altering rules can also be used to induce a separating equilibrium that both gives weight to contract law's dutyimposing functions and permits sophisticated parties to contract out of those duties. ${ }^{38}$

Attention to the interplay between contract law and the parties' nonlegal obligations suggests yet another amendment to Ayres's theory, the last that I will propose in this comment. Early in the article, Ayres distinguishes altering standards, which do not provide clear ex ante displacement conditions, from altering rules, the paradigm being rules that employ formal legal acts. ${ }^{39}$ Ayres does not explain why we might sometimes prefer an altering standard to an altering rule. The above argument suggests one answer: the value of hermeneutic altering rules,

${ }^{36}$ Klass, Intent to Contract, supra note 2 at 1472.

${ }^{37}$ Id. at 1473 .

${ }^{38}$ Ayres, Altering Rules, supra note 1 at 2088-92.

${ }^{39}$ Id. at 2037. 
which resist formulation in lists of necessary and sufficient conditions. But there is another answer as well.

Even if we care about the parties' legal intent-even if we want a juristic altering rule-the relational costs of requiring an express statement of that intent might sometimes be too high. ${ }^{40}$ Because contracts are also agreements, they often ride atop relationships of trust, honor and even friendship. Economists have long recognized that these extralegal forms of trust can provide more efficient and effective incentives than does the law. ${ }^{41}$ Where this is the case, a rule that requires parties to perform an otherwise cheap juristic act can end up imposing high relational costs on them. As Stuart Macaulay famously observed, "[b]usinessmen often prefer to rely on 'a man's word' in a brief letter, a handshake, or 'common honesty and decency' - even when the transaction involves exposure to serious risks." ${ }^{42}$ Legal formalities and express opt-outs run contrary to that preference.

Ayres does not systematically discuss the transaction costs that attach to different methods of avoiding a default. He touches on the costs of learning the rule, as well as specific costs that might come with errorreducing or impeding altering rules. But in all this, he neglects the relational costs of rules that require the parties to expressly state their legal intent. Where those costs are high, we might prefer a rule that ask courts to engage in an all-things-considered interpretation of the parties' legal intent, rather than one that asks the parties to state it at the time of contracting. ${ }^{43}$ Juristic altering standards are ceteris paribus preferable when requiring the parties to perform a juristic act is likely to do harm to valuable nonlegal forms of trust between them.

None of the above thoughts call into question the Big Idea of Regulating Opt-Out: that contracts scholarship stands in need of a general theory of altering rules. It does. And Ayres has provided an important piece of that theory. Even more valuably, he has clearly identified a question that more contract scholars should be trying to answer.

${ }^{40}$ I discuss such relational costs in Klass, Intent to Contract, supra note 2 at 1473-75.

${ }^{41}$ See, e.g., Robert C. Ellickson, Order without Law: How Neighbors Settle Disputes (1991); Eric Posner, Law and Social Norms (2000).

${ }^{42}$ Stuart Macaulay, Non-contractual Relations in Business: A Preliminary Study, 28 Am. Soc. Rev. 55, 58 (1963).

${ }^{43}$ See Klass, Intent to Contract, supra note 2 at 1465-69, 1496-97. 